\title{
Research on the College English Education Professional Personnel Training and the Docking of Middle and Primary School English Education Quality Improvement
}

\author{
Liwen $\mathrm{Yu}^{1}$ \\ 1Jiangxi Science \& Technology Normal University, \\ Nanchang,Jiangxi, 330038 China
}

\begin{abstract}
In this paper, we conduct research on the college English education professional personnel training and the docking of middle and primary school English education quality improvement. At present, applied English talents cultivation has become China's economic development and the inherent requirement of education development. Our research applied the quality improvement methodology into the training procedure. In view of the reality needs applied, compound talents training mode of research and design should become the key of the English teaching reform. In the future, we will conduct more research on the topic more in-depth.
\end{abstract}

Keywords: College English Education; Quality Improvement; Personnel Training; Docking Aim.

\section{Introduction}

With the deepening of China's reform and opening up and the adjustment of economic structure upgrade. Under the background of economic ties and with the world closer for all kinds of foreign language talents demand continues to increase, this brings to the English department and the whole English education discipline construction strong driving force. At present, applied English talents cultivation has become China's economic development and the inherent requirement of education development. Facing the new situation, English education needs to pay more attention to the quality of the ascension, structure optimization and the upgrading of talent on the comprehensive quality. Practice English talent is literally able to communication in English is very good use to the actual life, from the deep understanding, practice English talent should have the characteristics of the four aspects: first of all. Want to have a life and work ability, it is not to become a high score low-energy simple person; Second, to master English in aspects of theory knowledge, including the foreign cultural knowledge, basic knowledge such as grammar knowledge. If it is a business English major, but also need to master the knowledge of the aspects such as international trade process. Moreover, it is actual operation ability and key ability, practical ability is to apply what they have learned knowledge of English to work in real life, especially can help to solve the problem of work ability. The key ability is the autonomous learning ability, innovation ability of thinking. The combination of these two kinds of ability is the main characteristic of English practice talents again is good comprehensive quality, including in the work need to abide by the professional ethics of village qualitative and personal psychological quality [1-2].

In view of the reality needs applied, compound talents training mode of research and design should become the key of the English teaching reform. To the root of the society for talents demand as a starting point, really cultivate both meet the national standards and meet the needs of the reality of English professional talents, and gradually perfect the setting for English majors, through the rationalization of the teaching 
curriculum promoting the comprehensive qualities of the various levels of professional talents, highlight the scientific nature and rationality. National and social demand for English talents should become an important reference for the curriculum. Practice the concept of talent cultivation for higher vocational English education could be separated into the following pars. (1) In the choice of the compulsory courses and elective courses [3]. Through course arrangement can learn should learn the knowledge of practice English talent cultivation, but to the importance of the knowledge is to rely on the compulsory courses and elective courses to decide. (2) In the aspect of the comprehensive quality of talent cultivation practice English. As previously mentioned, practice talents is one of the characteristics of good quality. So on the arrangement of the course, in addition to learning about English knowledge and skills, but should also in the aspect of ideological and political study, including knowledge learning moral culture, laws and regulations, etc. (3) In different English professional set of practical ability training courses [4]. Although English mainly is the language of communication, in order to cultivate the students' professional which will be divided into different English major. (4) Give priority to in order to guide the way of teaching. In general, imparting knowledge is through the infusion. But on the basis of this approach is not improve the practice ability of students, so to adopt the way of to guide or lead students to learn to give priority to. (5) The integration of knowledge teaching way. For many teachers of English teaching used to separate words, grammar and translation teaching, in fact, the ways to achieve the teaching effect is not ideal. So in order to cultivate specialized talents for the idea of higher vocational English education should be oriented in separate teaching methods on the basis of the advantages of the original which will teach knowledge integrating teaching after consolidation [5].
In this paper, we conduct research on the college English education professional personnel training and the docking of middle and primary school English education quality improvement. The current English education of primary and secondary schools is the most serious problems that exist in the exam-oriented education is still occupy the mainstream, quality education is difficult to practical implementation. At present, the primary and secondary school English teachers is weak, especially in the rural primary school English teacher is very lack, some schools have not English teacher, some schools English teacher is a teacher of English majors in teachers' regular normal English major undergraduate course graduation, for the English course is strange, lack even the most basic teaching ability, there is no guarantee that the teaching effect and quality. Therefore, to largely strengthen the construction of primary and secondary school English teachers do a good job in English education is an urgent need to solve the first problem. In the next sections, we will discuss our proposed methodology in detail with theoretical analysis and demonstration.

\section{Our Proposed Approach and Method}

The General Introduction of College English Education. With the deepening of education reform, curriculum reform, method reform, reform mode reform and thoughts have become the basic form of teaching innovation. Performance in college English teaching, even optimization is to use the concept of quality education in English teaching, the teaching content, the method is suitable for students' awareness of the law, meet the students listening, speaking, reading and writing such as the formation of application ability. Abroad at present, many colleges and universities teaching and has a regular or irregular academic exchange or with foreign cooperation in running schools, at the same time, many professional teachers are also through various channels to improve their English level, which provides a teacher for 
English teaching innovation. College students the importance of learning English is the future in the internationalization of enterprises can communicate with foreign engineers, therefore, in the process of English teaching, to understand western culture, improve the students' communicative competence to foreign understand the western way of thinking, it is very important to be familiar with the western way of doing things [6]. Cross-cultural ability raise is the key and difficult point for English education in colleges and universities in our country.

However, the current education model has many drawbacks and disadvantages which are shown in the following. (1) Teaching model is too old. With the development of science and technology, the multimedia technology gradually extended to the college English classroom, but in the process of actual use did not give full play to its value, generally is the knowledge content of teachers will be needed before the blackboard writing way to students with multimedia which acquired no tangible improvement of results, on the other hand, in the process of teaching, teachers are blindly to guide students according to own thought idea which will imparts knowledge left intact to students, and seldom interaction between students, causing students involved in classroom to very hard, finally also cannot guarantee the classroom teaching efficiency. (2) The conflict of teaching contents and schedules. From the point of view of diversified and personalized, the teaching content should not only meet the actual needs of information interactive communication, at the same time should also conform to the actual development characteristics of students. But from the point of view of the current situation in college English class schedule can't meet the demand of practical teaching, now for non-professional English students, no week English course arrangement by significantly less. (3) Student participation is not strong enough for class teaching. Because teachers in the teaching process, do not pay attention to the exchange and interaction between students, so students often in a very passive state, under the influence of the situation, the result is unable to participate in the teaching of students, many students are afraid to speak, or to answer teachers' questions, gradually lose the interest in learning English. Therefore, the issues should be dealt with and solved.

The Middle and Primary School English Education. Primary and secondary school English education as the foundation of the university and the late English education which is backed by our government, schools and the broad masses of the people's attention which have been to several primary and middle school English teaching reform in our country, in order to better adapt to the needs of the development of China's economic development and personal. In recent years, with the opening of primary school English courses, with various levels of school freshmen enter junior high school which brings certain difficulty to junior high school junior English teaching. How to deal with good cohesion and transition of English teaching of primary and secondary schools, junior English teachers has become a junior high school is an urgent need to solve the problem. English teaching process is an organic whole and we absolutely can't leave middle school and primary school English disconnect. Primary and secondary school English organic cohesion is an important problem of junior middle school English teaching, is also the key to improve the quality of English teaching.

The most important transaction steps could be summarized as the follows. (1) Teaching method transaction. Primary school English teaching methods, forms, active classroom, students' learning interest, to speak actively, these are all worthy of junior middle school teachers. Precise knowledge and junior high school teachers pay attention to class, to student's unit knowledge through training, system knowledge review consolidate have unique method. We suggest, therefore, primary and secondary school teachers to go together, mutual listening to lectures, joint 
research, teaching and learning to know each other, form a good longitudinal academic communication atmosphere. (2) The cohesion of the learning method. Entered the stage of middle school teachers should also make students understand what habit and method should be further development along with the further study. At the first beginning, the teacher should not only targets for students ideological education, more want to be in their main link to improve the learning efficiency and quality. (3) Evaluation way. Entered a junior high school, obviously increased is the exam, which we are currently the main way of teaching evaluation for students. Basic education is crucial, primary and secondary school English interfaces for students to keep the interest of learning English as well as the coherence play an important role in English study for students.

Primary school English teaching and the teaching mode of activity focus on encouraging students to actively participate in, boldly imitate, let students learn while playing, increase feelings of language in the game. And middle school English is demands students to master to listen to, say, read, write and translation of comprehensive ability. The heavier the students' learning task. Elementary school is bigger than the mechanical memory understanding of knowledge memory. Elementary school students lack the ability to analyze and solve the problem of, are very much dependent on the teacher, their learning is often passive learning. While high school students are required to actively to analyze and solve problems, require students to active learning.

\section{The Docking of the Education Pattern.} Teaching innovation refers to the teacher in the actual teaching according to students' actual situation, with new teaching methods and means according to the syllabus, especially with the aid of multimedia teaching means to cultivate the students' foreign language comprehensive ability, make the students' foreign language ability and level of international standard with the world, to complete the prescribed by the ministry of education college foreign language teaching outline of all the teaching goal. To achieve this goal, we should establish the good teaching idea. In today's era of information civilization, knowledge economy has just beginning, science and technology talent competition heats up, in this case, we should abandon the "to the teacher as the center, as the center, classroom teaching as the center" of the traditional the outdated education idea, sets up "take the student as the center, guided by the teacher," the new education idea, implementing open teaching. In the process of the implementation of open teaching, teachers should give students the best learning space and freedom, encourage students to take an active part in all kinds of foreign language learning activities, such as video class, class discussion, English corner which help them form good independent study consciousness, only in this way, students' learning motivation can be persistent, to fully mobilize enthusiasm and learning outcomes can be present at an early date. The university curriculum reform requires us to change the teaching idea, intensify reform, two aspects of practical teaching and learning reform power to hinder success. Therefore, through the reform of the education, more teachers will equip with the necessary ability of teaching students.

\section{Conclusion}

In this paper, we conduct research on the college English education professional personnel training and the docking of middle and primary school English education quality improvement. The advent of the era of innovation for our university foreign language teachers provide opportunities for great talent, we have to keep on learning, innovative thinking, improving teaching methods, actively into the teaching reform, with their own hard work to promote the comprehensive work of college foreign language teaching. In view of the reality needs applied, compound talents training mode of research and design should become the key of the English teaching reform. To the root of the society for 
talents demand as a starting point, really cultivate both meet the national standards and meet the needs of the reality of English professional talents. We believe that through the proposed reform, more teachers will be equipped with the necessary ability of teaching students. In the future, we schedule to conduct more related literature review to modify the current methodology.

\section{Acknowledgement}

This research is financially supported by Jiangxi province education science the twelfth five-year guideline 2013 annual general projects. The project number is: 13 YB152.

\section{References}

[1] Msph L V R, Stockdale S E, Sapir N, et al. A patient-centered primary care practice approach using evidence-based quality improvement: rationale, methods, and early assessment of implementation.[J]. Journal of General Internal Medicine, 2014, 29 suppl 2(2 Supplement):589-597.

[2] Rui, Q. U. (2014). On the strategies of constructing primary and middle school students' comprehensive quality assessment. Journal of Heilongjiang College of Education.

[3] Claudet, J. (2014). Nurturing distributed leadership environments in schools: creative strategies for increasing community engagement and energizing school turnaround efforts. Open Journal.

[4] Shun-wing Ng, \& Tsan-ming Kenneth Chan. (2014). Continuing professional development for middle leaders in primary schools in hong kong. Journal of Educational Administration, volume 52.

[5] Boiko, O., Campbell, J. L., Elmore, N., Davey, A. F., Roland, M., \& Burt, J. (2014). The role of patient experience surveys in quality assurance and improvement: a focus group study in english general practice. Health Expectations An International Journal of Public Participation in Health Care.

[6] $\mathrm{Hu}$ Y J, Zhang M. Research and Improvement Strategies on Disaster Education for Primary and Secondary School[J]. Applied Mechanics \& Materials, 2014, 543-547. 